\title{
Optimization of Enzymatic Saccharification of Alkali Pretreated Typha angustifolia for Glucose Production
}

\author{
Arrisa Sopajarn and Chayanoot Sangwichien
}

\begin{abstract}
Lignocellulose ethanol is significantly sustainable bio-fuel. It is an environmentally friendly. This work is to develop a hydrolysis process of pretreated lignocellulose to ethanol production from narrow leaved cattail as a biomass material. Response surface methodology (RSM) with a central composite design (CCD) was followed to optimize the enzymatic saccharification process in order to obtain high glucose yield. Three independent variables (cellulase, $\beta$-glucosidase and temperature) that operating condition, vary at CCD five levels $(-\alpha,-1,0,+1,+\alpha)$. The optimum values for the predicted variables for glucose and xylose released were: cellulase loading 17.5 FPU/g substrate, $\beta$ - glucosidase loading $0 \mathrm{U} / \mathrm{g}$ substrate and hydrolysis temperature $55^{\circ} \mathrm{C}$. Under these optimal conditions, glucose and xylose yield reached to $413.25 \mathrm{mg} / \mathrm{g}$ substrate and $75.48 \mathrm{mg} / \mathrm{g}$ substrate, respectively. The results of a confirmation experiment under the optimum conditions agreed with model predictions.
\end{abstract}

Index Terms-Enzymatic saccharification, lignocellulose, RSM, narrow leaved cattail, glucose produced.

\section{INTRODUCTION}

An alternative energy is an important factor to increase the energy resources to instant fossil fuel. It has a limited availability. Bioethanol is popular considered interesting biofuel. It can be directly used in place of benzene or diesel. The blends of ethanol with gasoline in the Thai market are E10 (10\% of ethanol with $90 \%$ of gasoline), E20 ( $20 \%$ of ethanol with $80 \%$ of gasoline) and E85 (85\% of ethanol with $15 \%$ of gasoline) [1].

Narrow leaved cattail (Typha angustifolia) is a weed wetland plant in South East Asia. These have been used for phyto-remediation in constructed wetlands [2]. Lignocellulose is a main composition of cattail so it can be utilized as a biomass resource to convert to liquid fuels and chemicals that can partially replace petroleum and petrochemicals [3], [4]. A more sustainable solution would be to use cellulosic feedstock, which often can be obtained as waste from food crops or from non-food plants grown on marginal land [5]. Lignocellulosic biomass should be pretreated to facilitate biological conversions and to achieve commercial conversion potential [6]. The purpose of

Manuscript received October 25, 2014; revised December 9, 2014. This work was supported in part by Rajamangala University of Technology Srivijaya Rattaphum College.

A. Sopajarn is with the Department of Agricultural Machinery Technology, Rajamangala University of Technology Srivijaya Rattaphum College, Rattaphum, Songkhla 90180, Thailand (e-mail: am_rarrisa@hotmail.com).

$\bar{C}$. Sangwichien is with the Department of Chemical Engineering, Faculty of Engineering, Prince of Songkla University, Hat Yai, Songkhla 90112, Thailand (e-mail: chayanoot.s@psu.ac.th). pretreatment is to remove lignin and hemicelluloses, reduce cellulose crystallinity and increase the porosity of the materials. Cellulose, the major fraction of lignocellulosic biomass, can be hydrolyzed to glucose by acid or enzymes [7], [8].

Enzymatic hydrolysis lignocellulosics is advantageous over other physicochemical processes because enzymes catalyze only specific reactions. As a result no other side reaction occurs or byproducts are formed and the hydrolysis has the potential to achieve higher yield of reducing sugars [9]. Furthermore, it requires less energy and mild environment conditions. Thus the utility cost of the process is lower when compared to acid hydrolysis [10].

Response surface methodology (RSM) is a statistical model widely used to study and aggregate effect of several variables and to seek optimum conditions for a multivariable system [11]. It can reduce the number of experimental trials and evaluate the interactions between multiple of experimental parameters and observed results [12]. The objective of this present study was to optimize the process of enzymatic hydrolysis of pretreated narrow leaved cattail by using RSM whit three independent variables.

\section{MATERIAL AND METHOD}

\section{A. Material Preparation}

Narrow leaved cattail material with $70-80 \%$ moisture content was gathered from Ranod, Songkhla province, Thailand. Fresh of narrow-leaved cattail compositions are shown in Table I. It was chopped, washed to remove contaminated matters, and then dehydrated in oven-dried at $70^{\circ} \mathrm{C}$ for 3 days. The cattail was grounded with a hammer mill and sieved to a mesh size of $1 \mathrm{~mm}$. The stock material was stored in sealed plastic bags at room temperature for further use. Samples were analyzed for moisture content and ash content by using LAP \#001 and LAP \#005, respectively, which were developed by the National Renewable Energy Laboratory (NREL). The main compositions of sample were carried out according to the AOAC standard method [13].

\begin{tabular}{lc} 
TABLE I: NARROW LEAVE CATTAIL MATERIAL COMPOSITION \\
\cline { 2 - 2 } Narrow leaved cattail compositions & $\%(\mathrm{w} / \mathrm{w})$ \\
\hline moisture & $70-80$ \\
cellulose & 38.5 \\
hemicellulose & 37.6 \\
linin & 12.8 \\
ash & 11.1 \\
\hline
\end{tabular}

\section{B. Material Pretreatment}

The grounded cattail samples were soaked in $5 \% \mathrm{w} / \mathrm{v}$ $\mathrm{NaOH}$ solution at a sample loading of $10 \% \mathrm{w} / \mathrm{v}$. It was heated 
at $100^{\circ} \mathrm{C}$ in water bath for $120 \mathrm{~min}$. The pretreated cattail sample was washed with water until neutral $\mathrm{pH}$. After that, moisture content was determined before storing in a sealed plastic bag at $4^{\circ} \mathrm{C}$ to be used as substrate for the cellulose saccharification experiment.

\section{Enzyme Saccharification}

The pretreated cattail samples of 0.5 grams (dry weight) were mixed with a cellulase enzyme from Trichoderma reesei ATCC 26921 of 5, 10, 15, 20 and 25 FPU/g substrate, and $\beta$-glucosidase enzyme from Almonds Lyophyl of 0, 5, 10, 15 , and $20 \mathrm{U} / \mathrm{g}$ substrate, at $10 \mathrm{ml}$ of citric buffer ( $\mathrm{pH} 5.0$ ), all retained in screw capped Erlenmeyer flasks. Samples were incubated and heated at temperature of $30,35,40,45$, and $50^{\circ} \mathrm{C}$ in a water bath at $150 \mathrm{rpm}$ of shaking for $24 \mathrm{~h}$ hydrolysis time. After this reaction, the samples were cooled at room temperature, filtered and then centrifuged at 6000 rpm for $20 \mathrm{~min}$. The supernatant samples were used for sugar analysis by using HPLC analyzer (1100, Hewlett Packard, Germany) with Zorbax $\mathrm{NH}_{2}$ column and Refractive Index Detector (RID). The experimental results of cellulose saccharification were used in the analysis of the regression model with ANOVA by the Design-Expert 9.0.2 Trial version software with $\mathrm{CCD}$ technique.

\section{RSM Design for Enzyme Saccharification}

Response surface methodology (RSM) is generally used to investigate a combined effect of several variables and to find optimum conditions for a multivariable system [11]. That is an empirical modeling technique used to evaluate the relationship between a set of controllable experimental factors and observed results [12]. Optimization of cellulose saccharification was studied by using the Design Expert software (9.0.2 Trial version) with CCD experiments. CCD is the most common experimental design used in RSM which has equal predictability in all directions from the center and these are optimized designs for fitting quadratic model [14]. Cellulase enzyme loading, $\beta$-glucosidase enzyme loading, and hydrolysis temperature were assigned as the independent variables in this analyzed. These variables were used at five coded levels $(-\alpha,-1,0,+1,+\alpha)$ as showed in Table II.

TABLE II: CODED AND ACTUAL LEVELS OF THE INDEPENDENT VARIABLE FOR DESIGN OF EXPERIMENT

\begin{tabular}{lcccccc}
\multicolumn{7}{c}{ FOR DESIGN OF EXPERIMENT } \\
\cline { 3 - 7 } Independent variables & Code & \multicolumn{5}{c}{ Actual factor levels } \\
\cline { 3 - 7 } & $X_{1}$ & 5 & 10 & 15 & 20 & 25 \\
\hline $\begin{array}{l}\text { cellulase enzyme loading } \\
\text { (FPU/g substrate) }\end{array}$ & $X_{2}$ & 0 & 5 & 10 & 15 & 20 \\
$\begin{array}{l}\beta \text {-glucosidase enzyme } \\
\text { loading (U/g substrate) } \\
\text { hydrolysis temperature } \\
\left({ }^{\circ} \mathrm{C}\right)\end{array}$ & $X_{3}$ & 35 & 40 & 45 & 50 & 55 \\
\hline
\end{tabular}

\section{RESULT AND DISCUSSION}

A pretreatment process of lignocellulose could be getting an enzymatic saccharification in a higher yield than the un-pretreated one because the lignin in the plant cell wall is a barrier to enzyme action [7]. It was decreased the crystallinity of lignocellulose material. Therefore, the pretreated materials were higher degree porosity, higher external surface, and softer. After pretreated, material compositions consisted of
$65.8 \%$ cellulose, $16.2 \%$ hemicellulose, $12.1 \%$ lignin and $5.9 \%$ ash. Comparing the chemical components, alkali pretreatment increased the proportion of cellulose by $77.81 \%$ and decreased hemicellulose and lignin $80.59 \%$ and $20.12 \%$, respectively. The higher cellulose content and decreased hemicellulose and lignin content would allow for enhancement of enzymatic saccharification in a high yield of hydrolyzed sugar for ethanol biofuel.

On the basis of initial saccharification results, a cellulase enzyme concentration of 5-25 FPU/g substrate, a $\beta$-glucosidase enzyme concentration of $0-20 \mathrm{U} / \mathrm{g}$ substrate and temperature of $35-55{ }^{\circ} \mathrm{C}$ were tested as conditions for optimizing the saccharification process using RSM (see Table II).

TABLE III: EXPERIMENTAL DESIGN AND THE RESULT OF THE CENTRAL COMPOSITE DESIGN (CCD)

\begin{tabular}{cccccccc}
\hline \multirow{2}{*}{ Run } & $X_{1}$ & $X_{2}$ & $X_{3}$ & \multicolumn{2}{c}{ Glucose $(\mathrm{mg} / \mathrm{g})$} & \multicolumn{2}{c}{ Xylose $(\mathrm{mg} / \mathrm{g})$} \\
\cline { 6 - 8 } & & & & Observed & Predicted & Observed & Predicted \\
\hline 1 & 10 & 5 & 50 & 397.77 & 403.16 & 61.15 & 59.53 \\
2 & 15 & 10 & 45 & 398.79 & 385.92 & 91.97 & 84.63 \\
3 & 15 & 10 & 45 & 386.64 & 385.92 & 78.44 & 84.63 \\
4 & 15 & 20 & 45 & 381.04 & 368.73 & 56.46 & 48.75 \\
5 & 10 & 15 & 40 & 313.64 & 316.72 & 82.44 & 86.65 \\
6 & 5 & 10 & 45 & 364.26 & 356.73 & 101.50 & 94.61 \\
7 & 10 & 5 & 40 & 271.78 & 279.55 & 78.04 & 81.12 \\
8 & 10 & 15 & 50 & 385.95 & 402.71 & 62.24 & 72.64 \\
9 & 15 & 10 & 35 & 177.33 & 174.00 & 70.27 & 69.88 \\
10 & 20 & 5 & 40 & 276.17 & 277.35 & 101.25 & 93.13 \\
11 & 20 & 5 & 50 & 398.70 & 413.55 & 111.77 & 109.84 \\
12 & 15 & 0 & 45 & 365.75 & 360.13 & 65.88 & 71.31 \\
13 & 20 & 15 & 50 & 374.82 & 384.98 & 82.52 & 81.73 \\
14 & 15 & 10 & 55 & 410.80 & 396.19 & 74.46 & 72.57 \\
15 & 25 & 10 & 45 & 347.19 & 336.79 & 111.11 & 115.72 \\
16 & 20 & 15 & 40 & 273.86 & 286.40 & 53.55 & 57.45 \\
17 & 15 & 10 & 45 & 390.27 & 385.92 & 85.76 & 84.63 \\
\hline
\end{tabular}

The experimental results of saccharification by a complete three-factor-five level factorial experimental design, with three trials for replication of the central point, are shown in Table III. That is presented the experimental results by applying multiple regression analysis on the experimental data to investigate the effect of cellulase $\left(X_{1}\right), \beta$-glucosidase $\left(X_{2}\right)$ and temperature $\left(X_{3}\right)$ on enzymatic saccharification. The following second order polynomial equation was found to explain the glucose released and xylose released as a response variable in Eq. (1) and Eq. (2), respectively.

$$
\begin{aligned}
\text { Glucose }= & 385.923-9.967 X_{1}+4.302 X_{2}+111.092 X_{3} \\
& -28.115 X_{1} X_{2}+12.598 X_{1} X_{3}-37.624 X_{2} X_{3} \\
& -39.162 X_{1}^{2}-21.495 X_{2}^{2}-100.827 X_{3}^{2} \\
\text { Xylose }= & 84.627+10.555 X_{1}-11.285 X_{2}+1.348 X_{3} \\
& -41.213 X_{1} X_{2}+38.293 X_{1} X_{3}+7.576 X_{2} X_{3} \\
& +20.537 X_{1}^{2}-24.597 X_{2}^{2}-13.403 X_{3}^{2}
\end{aligned}
$$


where, Glucose is the predicted of glucose released; Xylose is the predicted of xylose released; $X_{1}, X_{2}$ and $X_{3}$ are the independent variable factors i.e. cellulase (FPU/g substrate), $\beta$-glucosidase (U/g substrate) and temperature $\left({ }^{\circ} \mathrm{C}\right)$, respectively.

TABLE IV: RESULT OF GLUCOSE RELEASED REGRESSION ANALYSIS OF

\begin{tabular}{lrrrrr}
\multicolumn{7}{c}{ Source } & Sum of Squares & df & Mean Square & $F$-value & $p$-value \\
\hline Model & 63838.550 & 9 & 7093.172 & 30.656 & $<0.0001$ \\
$X_{1}$ & 397.402 & 1 & 397.402 & 1.718 & 0.2314 \\
$X_{2}$ & 74.015 & 1 & 74.015 & 0.320 & 0.5893 \\
$X_{3}$ & 49365.870 & 1 & 49365.870 & 3 & $<0.0001$ \\
$X_{1} X_{2}$ & 395.236 & 1 & 395.236 & 1.708 & 0.2325 \\
$X_{1} X_{3}$ & 79.352 & 1 & 79.352 & 0.343 & 0.5765 \\
$X_{2} X_{3}$ & 707.771 & 1 & 707.771 & 3.059 & 0.1238 \\
$X_{1}^{2}$ & 1856.509 & 1 & 1856.509 & 8.024 & 0.0253 \\
$X_{2}^{2}$ & 559.308 & 1 & 559.308 & 2.417 & 0.1640 \\
$X_{3}^{2}$ & 12306.260 & 1 & 12306.260 & 53.186 & 0.0002 \\
Residual & 1619.670 & 7 & 231.381 & & \\
Lack of Fit & 1541.853 & 5 & 308.371 & 7.926 & 0.1158 \\
Pure Error & 77.816 & 2 & 38.908 & & \\
Cor Total & 65458.220 & 6 & & & \\
$R^{2}=0.9753$, adjusted $R^{2}=0.9434$ & & & \\
\hline
\end{tabular}

To fit the response function and experimental data, regression analysis was performed and the second order model for both responses was evaluated by NAOVA which are presented in TABLE IV and V. The regression for both the responses was statistically significant at $95 \%$ of confidence level. For the first response of glucose released, the model did not show any lack of fit and the determination
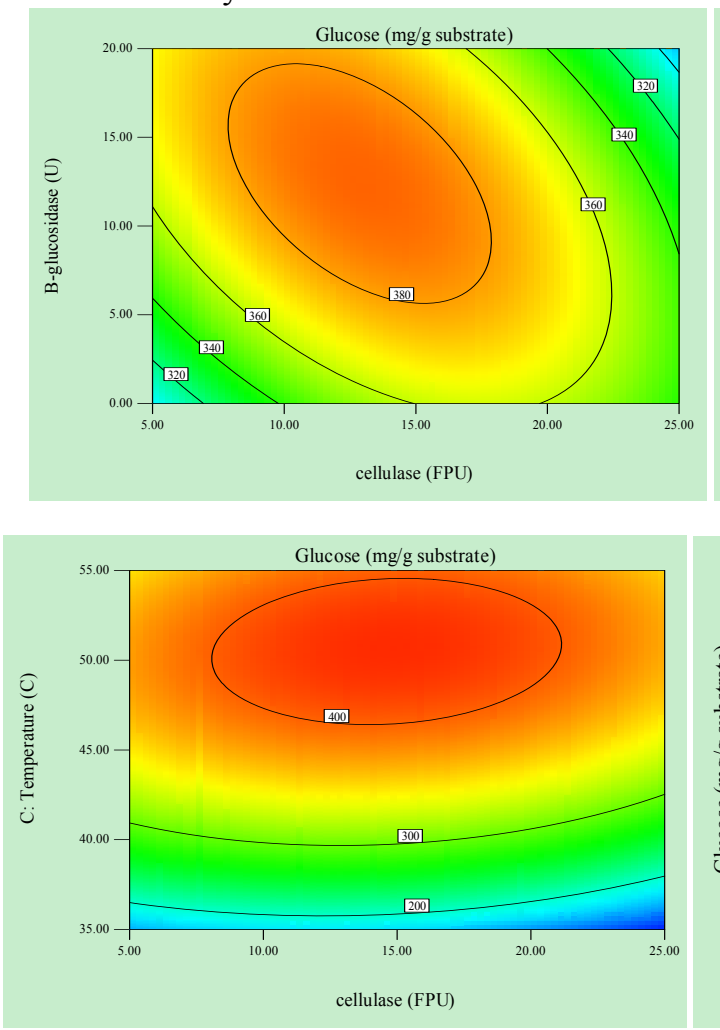

coefficient $\left(R^{2}\right)$ obtained was 0.9753 which explained $97.53 \%$ of the variability in response. The model F-value of 30.656 and p-value less than 0.0001 indicates that the model terms were significant [15]. ANOVA showed that temperature is the most effective variable of glucose released. The model of the second response of xylose released, also did not show any lack of fit and the determination coefficient $\left(R^{2}\right)$ obtained was 0.9102, which explained $91.02 \%$ of the variability in response. The model F-value of 7.886 and the small of p-value, less than 0.05 , indicates that the model terms were significant [16]. ANOVA showed that interaction of cellulase loading and $\beta$-glucosidase loading is the most effective variable of xylose released.

TABLE V: RESULT OF XYLOSE RELEASED REGRESSION ANALYSIS OF

\begin{tabular}{lrrrrr}
\multicolumn{7}{c}{ Source } & Sum of Squares & df & Mean Square & $F$-value & $p$-value \\
\hline Model & 4851.637 & 9 & 539.071 & 7.886 & 0.0063 \\
$X_{1}$ & 445.610 & 1 & 445.610 & 6.519 & 0.0379 \\
$X_{2}$ & 509.392 & 1 & 509.392 & 7.452 & 0.0293 \\
$X_{3}$ & 7.266 & 1 & 7.266 & 0.106 & 0.7539 \\
$X_{1} X_{2}$ & 849.235 & 1 & 849.235 & 12.423 & 0.0097 \\
$X_{1} X_{3}$ & 733.163 & 1 & 733.163 & 10.725 & 0.0136 \\
$X_{2} X_{3}$ & 28.694 & 1 & 28.694 & 0.420 & 0.5377 \\
$X_{1}^{2}$ & 510.571 & 1 & 510.571 & 7.469 & 0.0292 \\
$X_{2}^{2}$ & 732.357 & 1 & 732.357 & 10.713 & 0.0136 \\
$X_{3}^{2}$ & 217.454 & 1 & 217.454 & 3.181 & 0.1177 \\
Residual & 478.515 & 7 & 68.359 & & \\
Lack of Fit & 386.812 & 5 & 77.362 & 1.687 & 0.4125 \\
Pure Error & 91.703 & 2 & 45.851 & & \\
Cor Total & 5330.153 & 16 & & & \\
$R^{2}=0.9102$, adjusted $R^{2}=0.7948$ & & & & \\
\hline \multicolumn{7}{r}{} & & & &
\end{tabular}

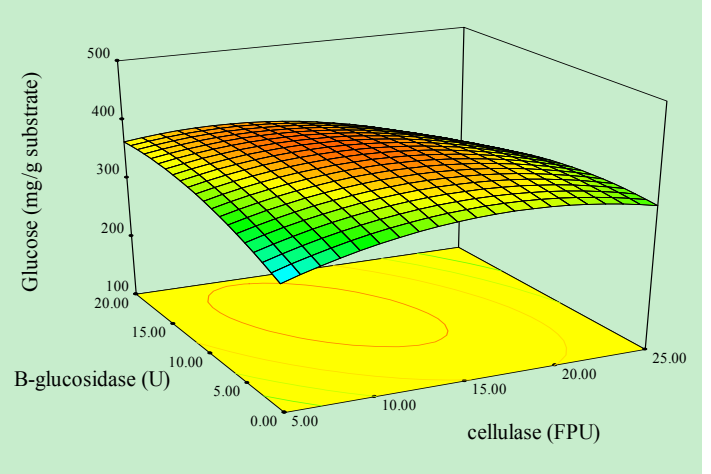

(A)

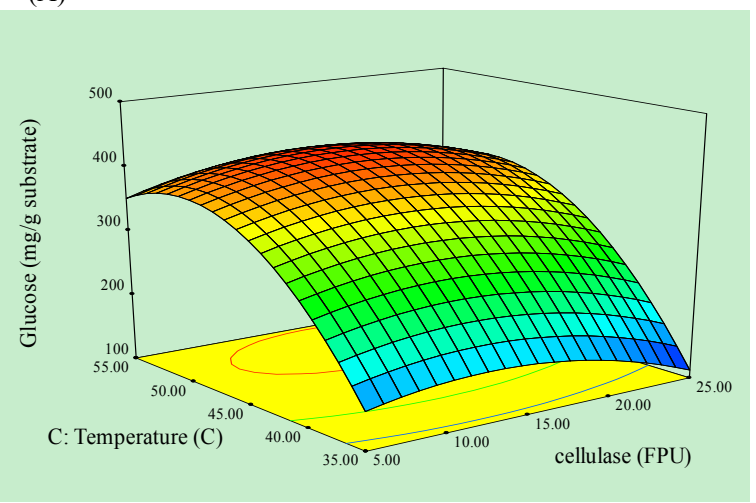

(B) 

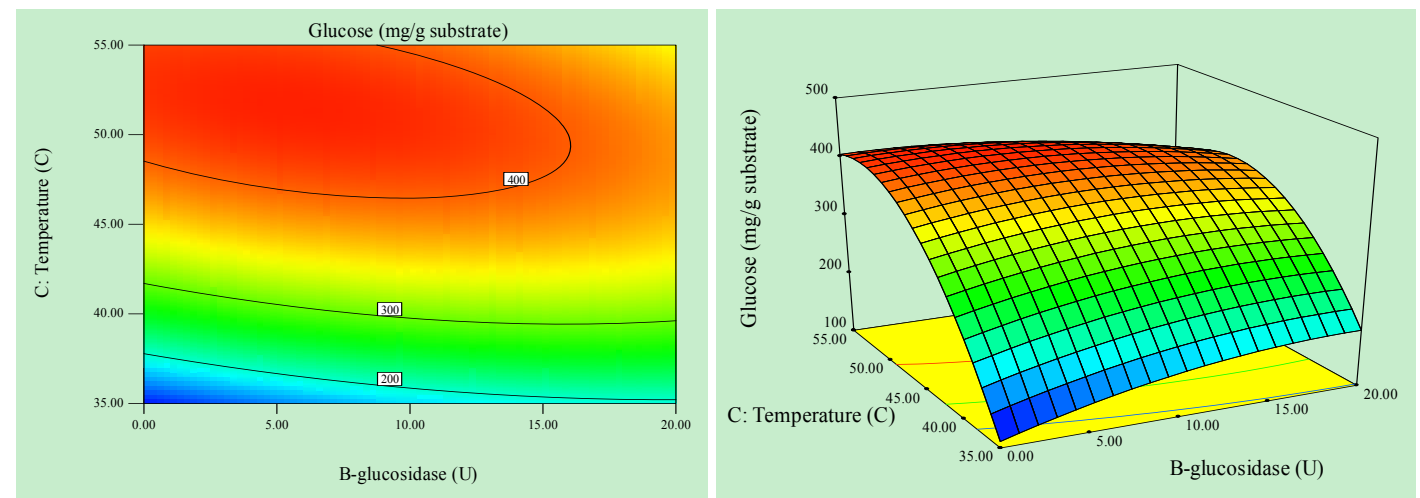

(C)

Fig. 1. Glucose released from enzymatic hydrolysis.
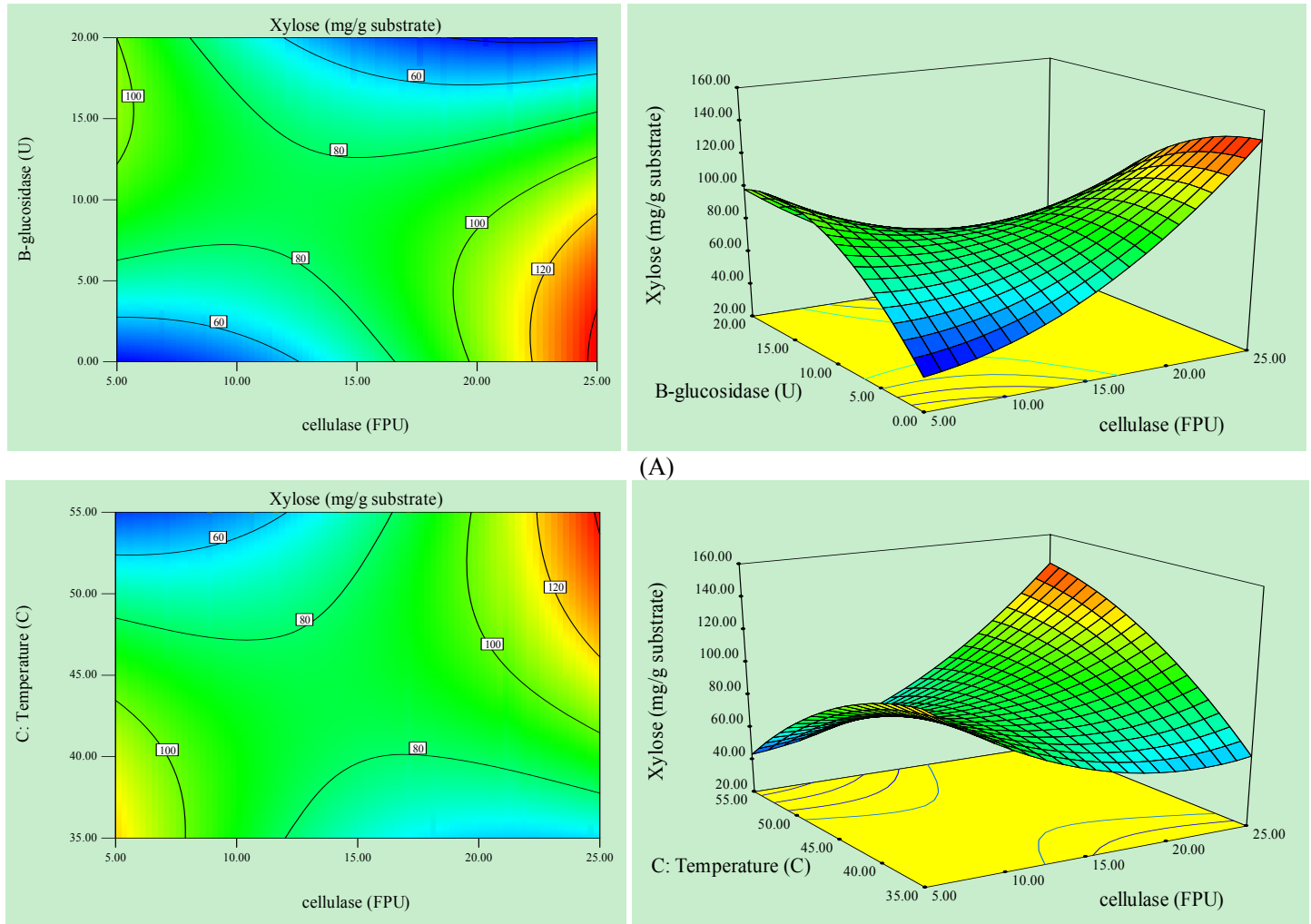

(A)

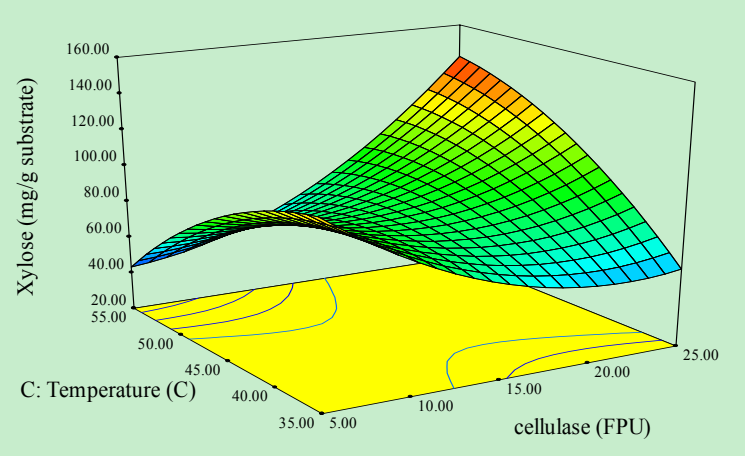

(B)
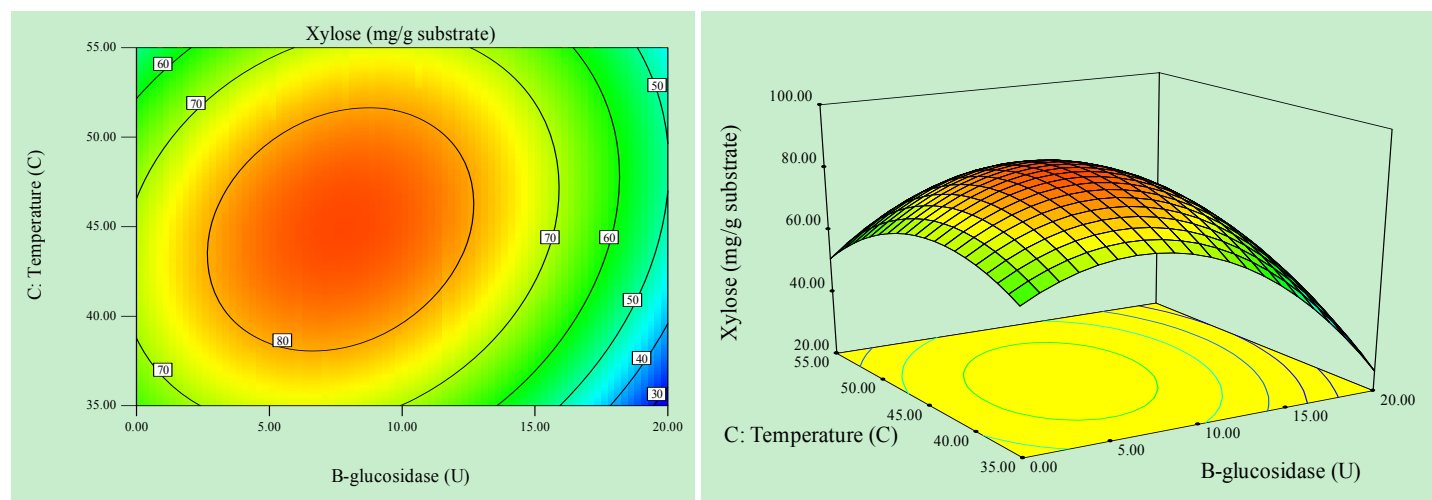

(C)

Fig. 2. Xylose released from enzymatic hydrolysis.

A response surface quadratic model was fitted to the data to determine the effect of cellulase, $\beta$-glucosidase and temperature on glucose and xylose yield from enzymatic saccharification of pretreated narrow leaved cattail. Fig. 1 and 2 are shown the estimation of both responses over two of independent variables at the center point of another variable. The modeling result is shown in Fig. 1 as a contour and 3D plots that showed the predicted peak in glucose concentration at the optimum. RSM determined the optimal saccharification condition to give highest concentration of glucose. Fig. 2 is also shown modeling result as a contour and $3 \mathrm{D}$ plots of xylose concentration at the optimum condition on the operating variables. Based on the glucose released, the optimal conditions were found as follows: cellulase 17.5 
FPU/g substrate, $\beta$-glucosidase $0 \quad \mathrm{U} / \mathrm{g}$ substrate, and temperature $55^{\circ} \mathrm{C}$. At the high enough of operating temperature, $\beta$-glucosidase is not needed to convert cellulose to glucose because the $\beta$-glucosidase, it alone cannot covert cellulose to glucose by itself; it can only change cellubiose to glucose [17]. Under these optimal conditions, glucose and xylose reached to $413.25 \mathrm{mg} / \mathrm{g}$ substrate and $75.48 \mathrm{mg} / \mathrm{g}$ substrate, respectively. The hydrolysis rate of cellulose fiber into cellubiose by a large amount of cellulase gets faster and intercepts the cellulase in the hydrolysis system to reach a near complete conversion. A very large amount of cellulase will create only cellubiose, and not the desirable glucose [17].

\section{CONCLUSION}

Lignocellulose substrate is a significant of biomass material to develop of ethanol biofuel. It can be replaced of food raw material. Main processes of lignocellulose ethanol production are pretreatment, hydrolysis and fermentation, should be suddenly develop to improve a high yield of lignolcellulose ethanol production.

For this research, Central Composite Design (CCD) and RSM designs have been proved to be effective in optimizing enzymatic saccharification using pretreated narrow leaved cattail. The optimal conditions were found as follows: cellulase $17.5 \mathrm{FPU} / \mathrm{g}$ substrate, $\beta$-glucosidase $0 \mathrm{U} / \mathrm{g}$ substrate, and temperature $55^{\circ} \mathrm{C}$. Under these optimal conditions, glucose and xylose reached to $413.25 \mathrm{mg} / \mathrm{g}$ substrate and $75.48 \mathrm{mg} / \mathrm{g}$ substrate, respectively. The result of enzymatic saccharification of pretreated narrow leaved cattail was in good agreement with the value predicted by the quadratic model, thereby confirming its validity.

\section{ACKNOWLEDGMENT}

We gratefully acknowledge the support by Rattaphum College, Rajamangala University of Technology Srivijaya, by the Graduate School of Prince of Songkla University and by the Department of Chemical Engineering, Faculty of Engineering, Prince of Songkla University (PSU).

\section{REFERENCES}

[1] C. Bloyd, "An update on ethanol production and utilization in Thailand," U.S. Deparment of Energy, 2009.

[2] K. Suda, A. Shahbazi, and Y. Li, "The feasibility of using cattails from constructed wetland to produce bioethanol," in Proc. the 2007 National Conference on Environmental Science and Technology, 2009, pp. 9-15.

[3] K. Krahmer, E. Wreh, and J. Rife, "Evaluation of pretreatment methods in the production of ethanol from cattail leaves," Journal of Unergraduate Research at Minnesota State University, 2009.

[4] B. Zhang, L. Wang, A. Shahbazi, O. Diallo, and A. Whitmore, "Dilute-sulfuric acid pretreatment of cattails for cellulose conversion," Bioresource Technology, vol. 102, pp. 9308-9312, Oct. 2011.

[5] B. Zhang, A. Shahbazi, and L. Wang, "Alkali pretreatment and enzymatic hydrolysis of cattails from constructed wetlands," American Journal of Engineering and Applied Sciences, vol. 3, no 2, pp. 328-332, 2010 .

[6] J. M. Lee, J. Shi, R. A. Venditti, and H. Jameel, “Autohydrolysis pretreatment of Coastal Bermuda grass for increased enzyme hydrolysis," Bioresource Technology, vol. 100, no. 24, pp. 6434-6441, Dec. 2009

[7] M. Jeya, Y. W. Zhang, I. W. Kim, and J. K. Lee, "Enhanced saccharification of alkali-treated rice straw by cellulase from Trametes hirsute and statistical optimization of hydrolysis conditions by RSM," Bioresource Technology, vol. 100, pp. 5155-5161, Nov. 2009.

[8] H. Watanabe, "The study of factors influencing the depolymerisation of cellulose using a solid catalyst in ionic liquids," Carboydrate Polymers, vol. 80, no. 4, pp. 1168-1171, May 2010.

[9] M. Mukhopadhyay, A. Kuila, D. K. Tuli, and R. Banerjee, "Enzymatic depolymerization of Ricinus communis, a potential lignocellulosic for improved saccharification," Biomass and Bioenergy, vol. 35, no. 8, pp. 3584-3591, Aug. 2011.

[10] S. Ferreira, A. P. Duarte, M. H. L. Ribeiro, J. A. Queiroz, and F. C. Domingues, "Response surface optimization of enzymatic hydrolysis of Cistus ladanifer and Cytisus straiatus for bioethanol production," Biochemical Engineering Journal, vol. 45, no. 3, pp. 192-200, 2009.

[11] J. K. Kim, B. R. Oh, H. J. Shin, C. Y. Eom, and S. W. Kim, "Statistical optimization of enzymatic saccharification and ethanol fermentation using foo waste," Process Biochemistry, vol. 43, pp. 1308-1312, Nov. 2008 .

[12] A. Singh, and N. R. Bishnoi, "Enzymatic hydrolysis optimization of microwave alkali pretreatment wheat straw and ethanol production by yeast," Bioresource Technology, vol. 108, pp. 94-101, Mar. 2012.

[13] AOAC, "AOAC method 973.18-Fiber (Acid Detergent) and Lignin in Animal Feeds," in Official Method of Analysis of the Association of Official Analytical Chemists, 15th ed., K. Helrick, Ed, vol. 82, Arlington, VA: Association of Official Analytical Chemists, 1990.

[14] Y. L. Gao, X. R. Ju, and H. H. Jiang, "Use of response surface methodology to investigate the effect of food constituents on Staphylococcus aureus inactivation by high pressure and mild heat," Process Biochem, vol. 41, pp. 362-369, Feb. 2006.

[15] J. H. Jo, D. S. Lee, D. Park, W. S. Cheo, and J. M. Park, "Optimization of key process variables for enhanced hydrogen production by Enterobacter aerogenes using statistical methods," Bioresource Technology, vol. 99, no. 6, pp. 2061-2066, Apr. 2008.

[16] K. W. Jung, D. H. Kim, H. Y. Kim, and H. S. Shin, "Optimization of combined (acid + thermal) pretreatment for fermentative hydrogen production from Laminaria japonica using response surface methodology (RSM)," International Journal of Hydrogen Energy, vol. 36, pp. 9626-9631, Jun. 2011.

[17] A. Ruangmee and C. Sangwichien, "Response surface optimization of enzymatic hydrolysis of narrow leaf cattail for bioethanol production," Energy Conversion and Management, vol. 73, pp. 381-388, May 2013.

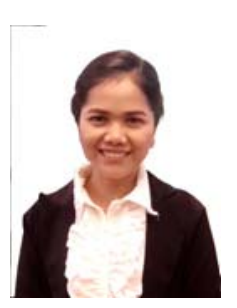

A. Sopajarn was born in Thailand, on March 23, 1985. She got the bachelor's degree of process engineering from Walailak University, Nakhon Si Thammarat, Thailand. She got the master degree and doctor of philosophy degree of Chemical Engineering from Prince of Songkla University, Songkhla, Thailand.

She is a teacher at Agricultural Machinery Technology, Rattaphum College, Rajamangala University of Technology Srivijaya, Thailand. Her research is mainly focused on biomass and alternative energy.

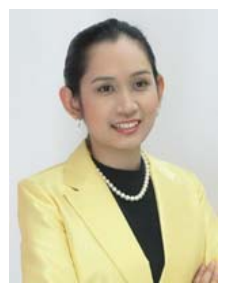

C. Sangwichien was born in Thailand, on May 24, 1974. She got the bachelor's degree of chemical engineering from Prince of Songkla University, Songkhla, Thailand. She got the master degree of chemical Engineering from Michigan technological University, USA. She got the doctor of philosophy degree of chemical engineering from Johns Hopkins University, USA.

Now, she is an associate professor at Prince of Songkla University, and also the head of chemical engineering department, Faculty of Engineering, Prince of Songkla University, Songkhla, Thailand. Her research is mainly focused on extraction of minor component from CPO, renewable energy i.e. biomass, biogas, value-added natural rubber product, and modeling on supercritical fluid adsorption. 
